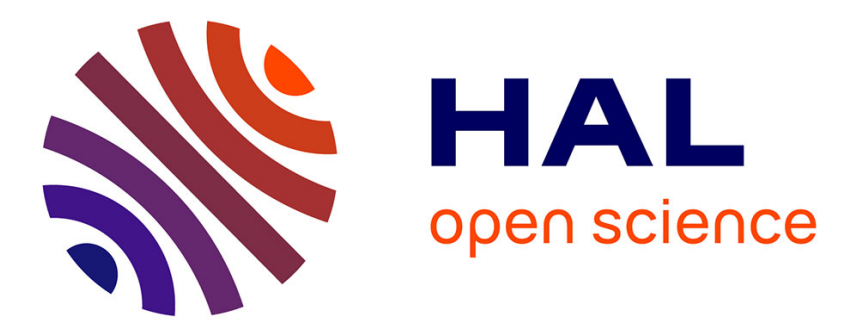

\title{
Study of gases released under incomplete combustion using PCFC-FTIR
}

\author{
Almanese Decimus, Rodolphe Sonnier, Pascal Zavaleta, Sylvain Suard, \\ Laurent Ferry
}

\section{- To cite this version:}

Almanese Decimus, Rodolphe Sonnier, Pascal Zavaleta, Sylvain Suard, Laurent Ferry. Study of gases released under incomplete combustion using PCFC-FTIR. Journal of Thermal Analysis and Calorimetry, 2019, 138 (1), pp.753-763. 10.1007/s10973-019-08160-5 . hal-02429079

\section{HAL Id: hal-02429079 https://hal.mines-ales.fr/hal-02429079}

Submitted on 30 Jan 2020

HAL is a multi-disciplinary open access archive for the deposit and dissemination of scientific research documents, whether they are published or not. The documents may come from teaching and research institutions in France or abroad, or from public or private research centers.
L'archive ouverte pluridisciplinaire HAL, est destinée au dépôt et à la diffusion de documents scientifiques de niveau recherche, publiés ou non, émanant des établissements d'enseignement et de recherche français ou étrangers, des laboratoires publics ou privés. 


\title{
Study of gases released under incomplete combustion using PCFC- FTIR
}

\author{
Almanese Decimus $^{1} \cdot$ Rodolphe Sonnier $^{1} \cdot$ Pascal Zavaleta $^{2} \cdot$ Sylvain Suard $^{2} \cdot$ Laurent Ferry $^{1}$
}

\begin{abstract}
In order to get new insights on cable behavior during real-scale fires, the gases released under incomplete combustion in pyrolysis combustion flow calorimeter were recorded for several PVC and halogen-free flame-retardant cables. Incomplete combustion was monitored by changing combustion temperature between 600 and $900{ }^{\circ} \mathrm{C}$. Gases were identified using PCFC-FTIR coupling. Quantitative assessment of different gases produced during combustion was also carried out. It appears that larger amounts of unburnt gases are produced for PVC cable at low temperature $\left(<650{ }^{\circ} \mathrm{C}\right)$. Moreover, $\mathrm{CO}$ release is observed for PVC cable up to $800{ }^{\circ} \mathrm{C}$ while this gas disappears between 700 and $750{ }^{\circ} \mathrm{C}$ for halogen-free flameretardant cables. Interestingly, the $\mathrm{CO}$ production is non-monotonous upon the temperature range investigated. These analyses would be useful to assess the risk of multiple re-ignitions during cable burning in real-scale fires, especially in confined compartments.
\end{abstract}

Keywords Incomplete combustion - Electrical cables · PVC · Pyrolysis combustion flow calorimeter

\section{Introduction}

Electrical cables represent a major cause of fire hazard in nuclear power plants (NPPs). Cables can be classified according to the materials composing their sheath. Polyvinyl chloride (PVC) and low-density polyethylene (LDPE), and its copolymers such as EVA (ethylene-vinyl acetate), are the main polymer types used for wire and cable insulation [1]. Since the 1950s, PVC has played a dominant role in cable sheathing due to its very good processing properties, flexibility and fire behavior. However, several tragic public fires demonstrated that the main

Rodolphe Sonnier

rodolphe.sonnier@mines-ales.fr

1 Ecole des Mines d'Alès, Centre des Matériaux des Mines d'Alès - Pôle Matériaux Polymères Avancés, 6 Avenue de Clavières, 30319 Alès Cedex, France

2 Institut de Radioprotection et de Sûreté Nucléaire (IRSN), PSN-RES, SA2I, LEF,

13115 Cadarache, St Paul-Lez-Durance Cedex, France dangers of PVC are related to smoke and toxic gases emission during combustion. Moreover, the potential health effect of phthalates (the main PVC plasticizer family) constitutes another drawback of this polymer. A new generation of halogen-free sheathing based on polyethylene flame-retarded with aluminum hydroxide (ATH) has progressively replaced a part of PVC cables.

Both types of cables are present in NPPs. To be used in such facilities, cables have to pass specific tests relative to flame propagation (IEC 60332-2) [2] or smoke emission (IEC 61034-2) [3]. Cables are also tested in trays to get closer from real installations [4]. These tests enable determining horizontal and vertical flame propagation rate in a stack of horizontal trays filled with cables. Cable trays are mainly encountered in confined rooms where combustion could be significantly influenced by the ventilation conditions. It has been shown in the literature that ventilation may affect the fire behavior and the decomposition products of different fuels such as hydrocarbon, alcohol, PMMA or wood [5-9] and also more complex products as cables [10]. Under-ventilated fires are characterized by the production of $\mathrm{CO}$ and other unburnt gases. As part of the OECD PRISME-2 project [11], Zavaleta et al. indeed showed that $\mathrm{CO}$ and unburnt hydrocarbon gases were produced from under-ventilated cable tray fire tests carried 
out in confined compartments [12, 13]. Successive ignitions of these unburnt gases and extinctions were then observed in the upper part of the fire compartment. The nature of released gases and their ability to be oxidized have obviously a great impact on the occurrence of the ignition events, and some efforts were thus made to determine the nature of the unburnt gases during the realscale fire tests [12]. Due to the large facility, some inaccuracies may remain and additional studies with detailed multi-gas characterizations are necessary.

In order to address this issue, this study aims at focusing on the analysis of gases released during the incomplete combustion of three cable sheaths: one PVC-based sheath and two halogen-free flame-retardant sheaths. A very useful laboratory-scale fire test is cone calorimeter, and different PVC and PE-based cables have already been tested using this device [14-16]. Nevertheless, cone calorimeter is a well-ventilated test and gases released correspond mainly to (almost) complete combustion. Therefore, this study is based on pyrolysis combustion flow calorimeter (PCFC) [17] and on the coupling between this apparatus and a Fourier transform infrared (FTIR) spectrometer [18]. PCFC has already been coupled with FTIR or alternatively to a $\mathrm{CO} / \mathrm{CO}_{2}$ gas analyzer [17-25]. Lyon's team is able to control continuously the ratio between fuels and $\mathrm{O}_{2}$ $[23,24]$ using a modified PCFC. Nevertheless, our apparatus does not allow such control. Therefore, it is not possible to directly study the role of the ventilation in PCFC. A more convenient possibility is to decrease the combustor temperature in order to reduce the combustion efficiency. This work is based on the reasonable assumption that data obtained from this procedure may be used to study the influence of under-ventilated conditions during real-scale fires.

\section{Experimental}

As sheath is the first component exposed to fire, all analyses described below have been carried out on cable sheath; other components of cables have not been taken into account. Three cables were considered (Fig. 1). Two of them are halogen-free flame-retardant cables (called A

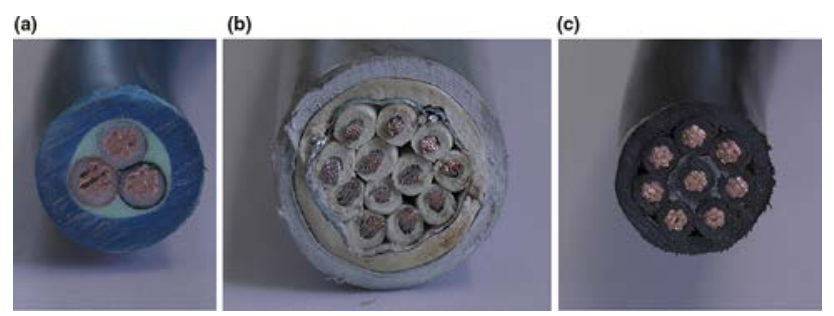

Fig. 1 From left to right, cables A, B and C and $\mathrm{B}$ ), and one is a PVC cable (called C). As the more severe ignitions (i.e., those which led to the highest pressure peaks) occurred for the PVC cable (C) $[13,26]$, the article focuses on it. The results for cables A and B are briefly presented and compared with cable $\mathrm{C}$ in the last part of the work. The two first cables are EVA/PE cables, filled with around 60 mass $\%$ of aluminum hydroxide (ATH). Trimethylolpropane trimethacrylate (TMPTMA) was identified by Py-GC/MS in cable B sheath, evidencing that the sheath has been cross-linked. Their flammability has been studied in detail using cone calorimeter tests [14].

Carbon contents in sheath and residue (after anaerobic pyrolysis in TGA) were measured with a energy-dispersive $\mathrm{x}$-ray detector coupled with a SEM microscope (FEI Quanta 200 SEM).

$\mathrm{X}$-ray diffraction (DRX) patterns were recorded on a Bruker AXS D8 Advance X-ray powder diffractometer using the $\mathrm{Cu} \mathrm{K} \alpha$ radiation. The powders are compacted with a glass slide for analysis.

The Py-GC/MS analytical setup consisted of an oven pyrolyzer connected to a GC/MS system. A Pyroprobe 5000 pyrolyzer (CDS Analytical) was used to pyrolyze the samples in a helium environment. This pyrolyzer is supplied with an electrically heating platinum filament. One coil probe enables the pyrolysis of samples (less than $1 \mathrm{mg}$ ) placed in quartz tube between two pieces of quartz wool. The sample is successively heated at $300,400,500$ and $600{ }^{\circ} \mathrm{C}$. Each temperature was held for $15 \mathrm{~s}$ before gases were drawn to the gas chromatograph for $5 \mathrm{~min}$. The pyrolysis interface was coupled to a 450-GC gas chromatograph (Varian) by means of a transfer line heated at $270{ }^{\circ} \mathrm{C}$. In this oven, the initial temperature of $70^{\circ} \mathrm{C}$ was held for $0.2 \mathrm{~min}$ and then raised to $310{ }^{\circ} \mathrm{C}$ at $10{ }^{\circ} \mathrm{C} \mathrm{min}-1$. The column is a Varian Vf-5 ms capillary column $(30 \mathrm{~m} \times 0.25 \mathrm{~mm})$, and helium $\left(1 \mathrm{~mL} \mathrm{~min}^{-1}\right)$ was used as the carrier gas; a split ratio was set to 1:50. The gases were introduced from the GC transfer line to the ion trap analyzer of the 240-MS mass spectrometer (Varian) through the direct coupled capillary column. Identification of the products was achieved comparing the observed mass spectra to those of the NIST mass spectral library.

Thermogravimetric analyses were carried out using a Setaram Sestys apparatus. The heating rate was fixed at $60{ }^{\circ} \mathrm{C} \mathrm{min}{ }^{-1}$ under nitrogen flow up to $800{ }^{\circ} \mathrm{C}$.

Pyrolysis combustion flow calorimetry (FTT, United Kingdom) was used to study the combustion efficiency and the gases released under incomplete combustion. The procedure has been explained in previous work [17]. Pyrolysis is anaerobic from 100 to $750{ }^{\circ} \mathrm{C}$ at $60{ }^{\circ} \mathrm{C} \mathrm{min}-1$, and gases are sent to a combustor in excess of oxygen (ratio $\mathrm{O}_{2} / \mathrm{N}_{2}=0.2$ ) during $10 \mathrm{~s}$, at different temperatures (between 600 and $900{ }^{\circ} \mathrm{C}$ ). At $900{ }^{\circ} \mathrm{C}$, combustion is complete. When temperature of combustion decreases, the 
combustion becomes more and more incomplete and different carbon-containing species are observed. Energy released is calculated using oxygen depletion method according to Huggett's relation. Combustion efficiency is calculated according to Eq. (1):

$\chi_{\mathrm{T}}=\frac{\Delta_{\mathrm{O}_{2} \mathrm{~T}}}{\Delta_{\mathrm{O}_{2} 900}}=\frac{\mathrm{THR}_{\mathrm{T}}}{\mathrm{THR}_{900}}$

with $\Delta_{\mathrm{O}_{2} \mathrm{~T}}$ and $\mathrm{THR}_{\mathrm{T}}$ the oxygen consumed and the total heat released at combustor temperature equal to $\mathrm{T}^{\circ} \mathrm{C}$.

Of course, pyrolysis combustion flow calorimetry does not represent an actual fire situation, especially because combustion and pyrolysis are well separated (there is no heat feedback from the flame to the burning material). Moreover, the sample is very small and no thermal gradient is expected. But this method allows a very good control of fire conditions and is very suitable to a deep understanding of pyrolysis and combustion phenomena.

In order to analyze gases, from anaerobic pyrolysis and from combustion at different temperatures, Fourier transform infrared (FTIR) spectrometer Nicolet iS10, from Thermo Fisher Scientific, was coupled successively to TGA and PCFC, via a 2-m heated transfer line. The temperatures of the transfer line and of the gas cell were fixed at 160 and $165{ }^{\circ} \mathrm{C}$, respectively. The cell path length is $84 \mathrm{~mm}$, and the detector is DTGS (deuterated triglycine sulfate). FTIR spectra were recorded in the $400-4000 \mathrm{~cm}^{-1}$ range with a resolution fixed to $0.5 \mathrm{~cm}^{-1}$. Acquisition time, optical velocity and scan number were, respectively, set to $10 \mathrm{~s}, 0.4747 \mathrm{~cm} \mathrm{~s}^{-1}$ and 2 in order to obtain a sufficiently high acquisition frequency with regard to the chosen heating rate. Spectra were studied using Omnic software from Thermo Fisher Scientific.

Note that combustion efficiency is modified only by changing combustion temperature. Another possibility may be to change oxygen content in combustor [27]. Unfortunately, the ratio between oxygen and fuel changes continuously during a test. Therefore, it is not possible to study the ability of gases to be oxidized at fixed ratio between oxygen and fuels. As already stated in introduction, works based on a continuous control of the ratio between oxygen and fuel (i.e., equivalence ratio) can be found elsewhere using a modified PCFC [23, 24].

\section{Methodology}

No calibration was available to assess the amount of different gases from TGA-FTIR or PCFC-FTIR couplings. In order to estimate the mass fractions of carbon released into $\mathrm{CO}_{2}, \mathrm{CO}$ or other gases, the following method was used. The content of carbon fractions in the sheath before pyrolysis, $f_{\mathrm{c}}$, and in the residue after pyrolysis, $f_{\mathrm{cc}}$, was measured using EDX-SEM and allows an estimation of the carbon content, obtained in the gaseous phase $f_{\mathrm{cg}}$.

$f_{\mathrm{c}}=X \times f_{\mathrm{cc}}+(1-X) \times f_{\mathrm{cg}}$

with $X$ the residue content.

When combustion is complete (i.e., at $900{ }^{\circ} \mathrm{C}$ ), the carbon fraction released is fully oxidized into $\mathrm{CO}_{2}$ in the combustor (i.e., $f_{\mathrm{cg}}=f_{\mathrm{CO}_{2}}$ ). According to the Beer-Lambert law, the absorbance of species is proportional to its concentration. Therefore, $f_{\mathrm{CO}_{2}}$ is proportional to the area under the $\mathrm{CO}_{2}$ band $A_{\mathrm{CO}_{2}}$ (between 2200 and $2400 \mathrm{~cm}^{-1}$ ). This allows calculating the proportionality factor $k_{\mathrm{CO}_{2}}$ between $\mathrm{CO}_{2}$ concentration and the area under the $\mathrm{CO}_{2}$ band.

$k_{\mathrm{CO}_{2}}=\frac{f_{\mathrm{cg}}}{A_{\mathrm{CO}_{2}}}=f_{\mathrm{CO}_{2}}$

At lower temperature, the carbon fraction is not fully oxidized and $\mathrm{CO}$ is released concomitantly with $\mathrm{CO}_{2}$. Therefore, $f_{\mathrm{cg}}=f_{\mathrm{CO}_{2}}+f_{\mathrm{CO}}$. The proportionality factor $k_{\mathrm{CO}}$ between $\mathrm{CO}$ concentration and the area under $\mathrm{CO}$ band $A_{\mathrm{CO}}$ (between 2000 and $2200 \mathrm{~cm}^{-1}$ ) is calculated as follows:

$k_{\mathrm{CO}}=\frac{f_{\mathrm{cg}}-k_{\mathrm{CO}_{2}} A_{\mathrm{CO}_{2}}}{A_{\mathrm{CO}}}$

and

$f_{\mathrm{CO}}=k_{\mathrm{CO}} A_{\mathrm{CO}}$

Finally, at the lowest temperatures, carbon-containing combustion products include not only $\mathrm{CO}_{2}$ and $\mathrm{CO}$ but also poorly or non-oxidized molecules (e.g., methane). The fraction of these molecules $f_{\text {other }}$ is estimated as follows:

$f_{\text {other }}=f_{\mathrm{cg}}-f_{\mathrm{CO}_{2}}-f_{\mathrm{CO}}$

This procedure allows calculating the fractions of the different species released from the combustor for each combustor temperature. Note that areas under $\mathrm{CO}_{2}$ and $\mathrm{CO}$ bands were divided by the exact initial sample mass for each analysis.

The residue content $X$ from cable $\mathrm{C}$ sheath pyrolysis is $18 \%$. The carbon fractions in the sheath $f_{\mathrm{c}}$ and in the residue $f_{\mathrm{cc}}$ are, respectively, 0.63 and 0.57 . Therefore, the carbon fraction released in the gaseous phase $f_{\mathrm{cg}}$ is 0.64 . From these results, the proportionality factors $k_{\mathrm{CO}_{2}}$ and $k_{\mathrm{CO}}$ are 9.3 and 11.8 , respectively.

Note that in this work gas concentration is considered as proportional to absorbance. Linearity between concentration and absorbance may be not fully ensured, especially at high concentration. 


\section{Results and discussion}

\section{Analysis of the PVC cable sheath}

TG analysis was carried out on the sheath under nitrogen flow (anaerobic pyrolysis). Two decomposition steps can be observed (Fig. 2). The first one corresponds to the release of $\mathrm{HCl}$ from $\mathrm{PVC}$ and to phthalate decomposition. The second one is probably associated with the decomposition of the PVC backbone but also of $\mathrm{CaCO}_{3}$ which releases $44 \%$ of $\mathrm{CO}_{2}$. While $\mathrm{CaCO}_{3}$ decomposition occurs usually at higher temperature, a reaction with $\mathrm{HCl}$ is expected as evidenced by the presence of $\mathrm{CaCl}_{2}$ at relatively low temperature.

Elemental analysis by EDX-SEM was carried out on the sheaths before and after anaerobic pyrolysis. Table 1 shows the contents in certain elements. Carbon and chlorine can be assigned to the PVC matrix (and also phthalate for carbon). $\mathrm{Ca}$ evidences the presence of calcium carbonate. $\mathrm{Pb}$ reveals the presence of a lead-stabilizing agent which is quite common for PVC [28]. O comes from these two components as well as from plasticizer (phthalate). After anaerobic pyrolysis, C content tends to slightly decrease. $\mathrm{Cl}$ content is divided by two due to the release of $\mathrm{HCl}$ during the first step of decomposition. Nevertheless, a significant part of chlorine remains into the residue. It is due to the reaction between calcium carbonate and chlorine, leading to $\mathrm{CaCl}_{2}$ species. Calcium carbonate and calcium hydroxide are used to prevent the release of halogenated species $[29,30] . \mathrm{CaCl}_{2}$ is well observed by EDX-SEM even at low temperature $\left(370{ }^{\circ} \mathrm{C}\right.$, i.e., during the first decomposition step). Indeed, $\mathrm{Ca}$ and $\mathrm{Pb}$ elements are observed in the same areas (Fig. 3b, c). Of course, Ca and $\mathrm{Pb}$ remain mainly in the residue. Therefore, their contents are much higher into the residue than into the sheath.

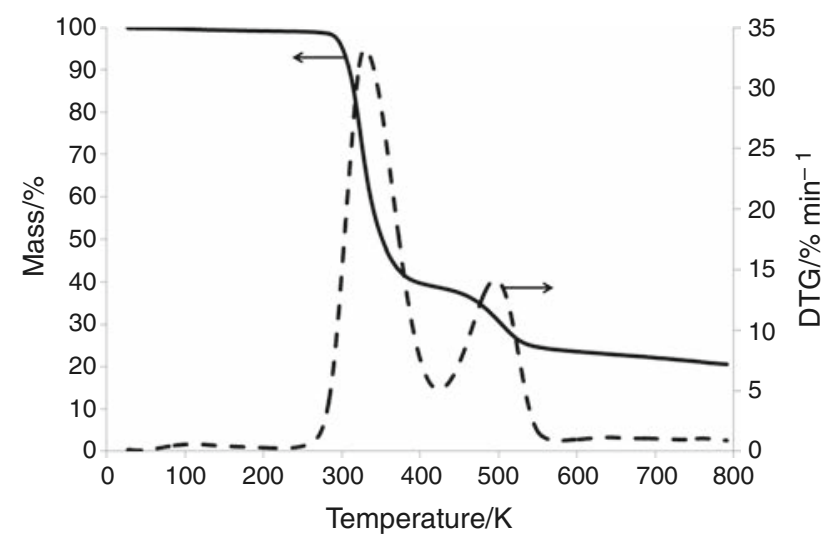

Fig. 2 TG and derivative thermogravimetric curves for the cable $\mathrm{C}$ sheath
Table 1 Elemental analysis of the cable $\mathrm{C}$ sheath and residue after anaerobic pyrolysis

\begin{tabular}{lll}
\hline \multicolumn{2}{l}{ Element content/mass\% } \\
\hline $\mathrm{C}$ & In sheath & In residue (after anaerobic pyrolysis) \\
$\mathrm{O}$ & 62.91 & 57.09 \\
$\mathrm{Cl}$ & 10.16 & 12.21 \\
$\mathrm{Ca}$ & 22.86 & 11.85 \\
$\mathrm{~Pb}$ & 1.61 & 10.05 \\
\hline
\end{tabular}

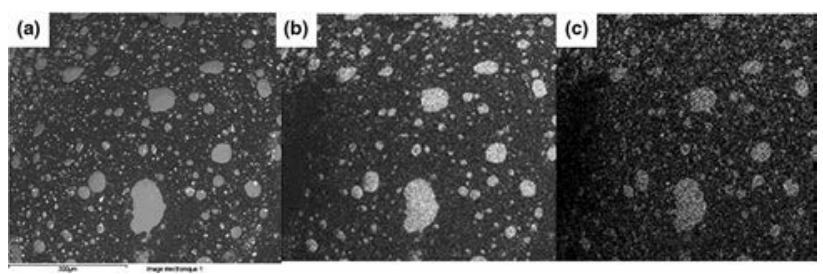

Fig. 3 a SEM pictures of cable $\mathrm{C}$ sheath after anaerobic pyrolysis at $370{ }^{\circ} \mathrm{C}$; b $\mathrm{Cl}$ mapping; $\mathbf{c}$ Ca mapping

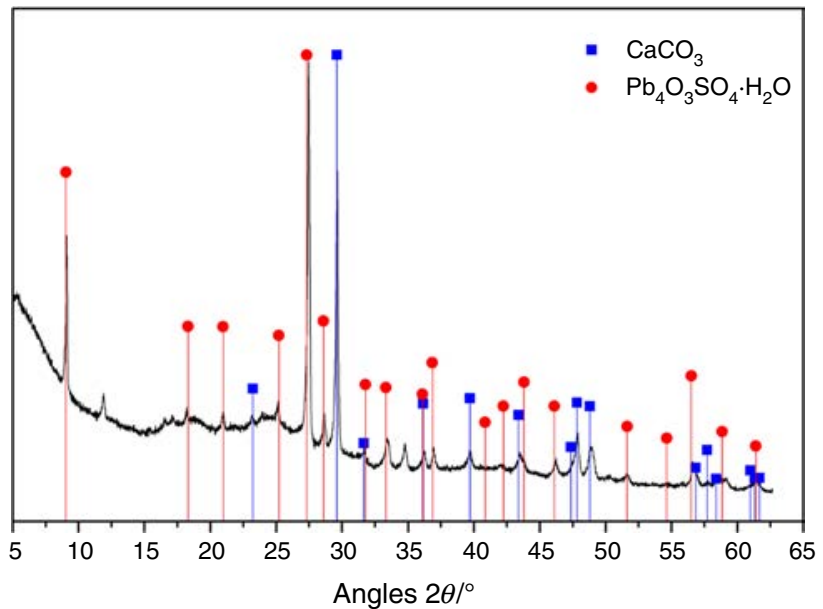

Fig. 4 X-ray diffraction spectrum for the cable $\mathrm{C}$ sheath

The X-ray diffractogram of the sheath is shown in Fig. 4. The presence of calcium carbonate and $\mathrm{Pb}$-based stabilizer (as lead oxide sulfate hydrate) is confirmed especially from peaks at $29.5^{\circ}$ and $27.2^{\circ}$, respectively. S element was not detected by EDX-SEM, probably because its content is very low.

Py-GC/MS was used to have an insight on components from the identification of their decomposition products (Fig. 5). At low temperature $\left(<500{ }^{\circ} \mathrm{C}\right)$, several products can be assigned to the decomposition of phthalate, and especially of dioctyl phthalate (DOP): phthalic acid, 2-ethyl hexanol and benzene [31]. Alcenes are also observed. At higher temperature $\left(\geq 500{ }^{\circ} \mathrm{C}\right)$, aromatic 
Fig. 5 Py-GC/MS spectra for the cable $\mathrm{C}$ sheath at different pyrolysis temperatures

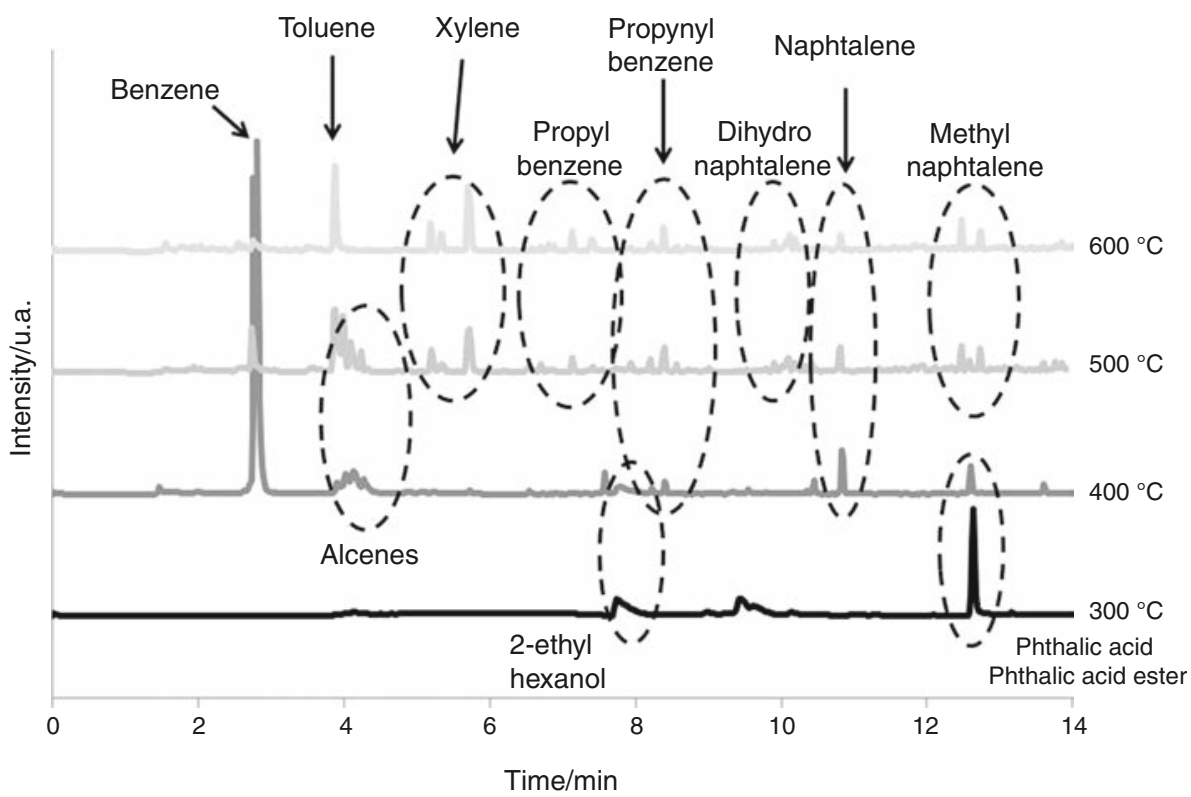

molecules can be assigned to the decomposition of rearranged $\mathrm{PVC}$ structure after $\mathrm{HCl}$ release.

All these findings (multiple decomposition steps of PVC insulation, release of phthalate during the first step along with $\mathrm{HCl}$, decomposition of $\mathrm{CaCO}_{3}$ and formation of $\mathrm{CaCl}_{2}$ ) have already noted by Benes et al. [32].

Considering the low initial $\mathrm{Cl}$ content in sheath (22.9 mass\% versus 56 mass\% in pure PVC), it can be considered that PVC content is only 41 mass\% in sheath. From $\mathrm{Ca}$ and $\mathrm{Pb}$ content into sheaths (Table 1), it can be calculated that $\mathrm{CaCO}_{3}$ content is around 4 mass $\%$ and hydrated lead oxide sulfate content is around 3 mass $\%$. It means that phthalate content would be higher than 50 mass\%. Considering that all $\mathrm{HCl}$ and phthalates are released during the first decomposition step, the mass loss should reach 75 mass $\%$. Nevertheless, the mass loss for the first peak is actually 60 mass\%. The reactions between calcium carbonate and chlorine may explain this discrepancy. TG analyses will show that $\mathrm{HCl}$ is released not only during the first step but also during the second one.

\section{Gases released from anaerobic pyrolysis and combustion at different temperatures}

Gases were firstly identified after anaerobic pyrolysis using the TGA-FTIR coupling. Figure 6 shows the spectra recorded at the decomposition peaks (i.e., at 320 and $490{ }^{\circ} \mathrm{C}$ ). $\mathrm{HCl}$ is the main gas released during the first peak (bands between 2600 and $3200 \mathrm{~cm}^{-1}$ ). $\mathrm{CO}_{2}$ is also observed between 2200 and $2400 \mathrm{~cm}^{-1}$. A peak centered at $1800 \mathrm{~cm}^{-1}$ may be assigned to phthalates. Peaks between 2800 and $3000 \mathrm{~cm}^{-1}$ (under the main narrow peaks related to $\mathrm{HCl}$ ) correspond to aliphatic carbons. $\mathrm{HCl}$ is still

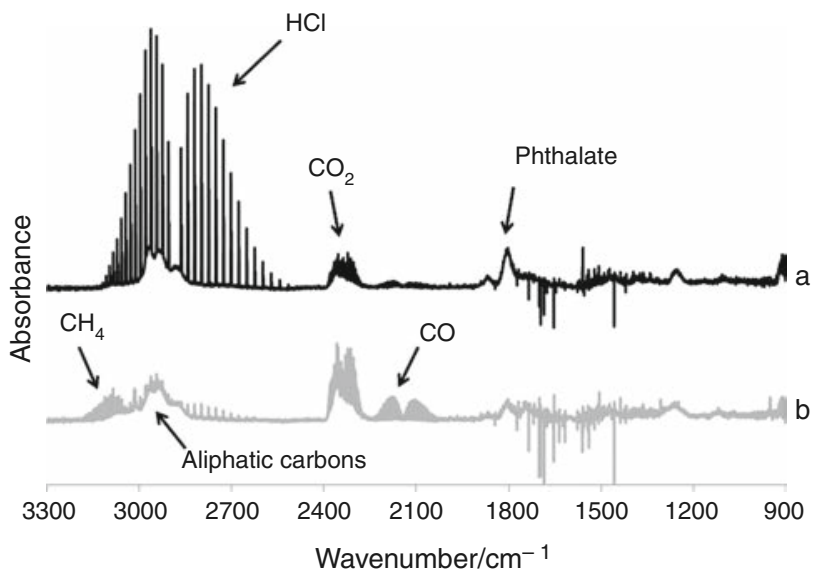

Fig. 6 TGA-FTIR spectra for the cable C sheath: a first decomposition peak; $\mathbf{b}$ second decomposition peak

observed during the second peak, but its intensity is much lower. $\mathrm{CO}_{2}, \mathrm{CO}$ and phthalate are observed ( $\mathrm{CO}$ bands appear between 2000 and $2200 \mathrm{~cm}^{-1}$ ). Peaks between 2800 and $3000 \mathrm{~cm}^{-1}$ corresponding to aliphatic carbons are much more significant. Narrow bands above $3000 \mathrm{~cm}^{-1}$ are assigned to methane.

Note that the main gases identified here $\left(\mathrm{CO}, \mathrm{CO}_{2}, \mathrm{HCl}\right.$, $\mathrm{CH}_{4}$ ) cannot be observed using Py-GC/MS. Conversely, some gases observed in Py-GC/MS (Fig. 5) as benzene and derivatives are not well identified using TGA-FTIR. We assume that the production of these gases is very limited and bands appear in noisy range of wavenumbers (around $1500 \mathrm{~cm}^{-1}$ ) or are overlapped by other bands.

Figure 7 shows the heat release rate curves for different combustion temperatures. Heat release is reduced when temperature decreases below $700{ }^{\circ} \mathrm{C}$. It corresponds to a 


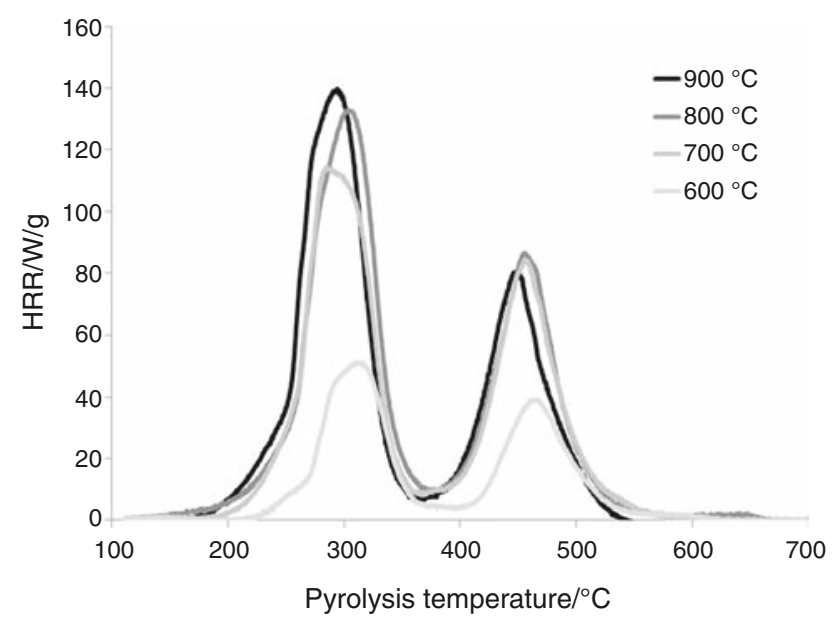

Fig. 7 Heat release rate curves for sheath from cable $\mathrm{C}$ at different combustion temperatures

decrease in the combustion efficiency and the production of poorly oxidized gases (see below). Note that the first peak of heat release rate decreases faster than the second one. Indeed, the first peak is around $140 \mathrm{~W} \mathrm{~g}^{-1}$ at $900{ }^{\circ} \mathrm{C}$. It starts to decrease at $750{ }^{\circ} \mathrm{C}$. At $600{ }^{\circ} \mathrm{C}$, its intensity is $50 \mathrm{~W} \mathrm{~g}^{-1}$, i.e., only $36 \%$ of its initial value (50/ $140=0.36)$. The second peak is $80-90 \mathrm{~W} \mathrm{~g}^{-1}$ even at $700{ }^{\circ} \mathrm{C}$. At $600{ }^{\circ} \mathrm{C}$, its intensity is $40 \mathrm{~W} \mathrm{~g}^{-1}$, i.e., $44-50 \%$ of its initial value. Similarly, the energy released during the first step (i.e., the area under the first peak) decreases faster (Fig. 8-note that some combustion efficiency values are slightly higher than 1 due to uncertainties measurements). This is particularly obvious between 675 and $750{ }^{\circ} \mathrm{C}$. It means that the combustion of gases released during the first step becomes incomplete more easily than that of gases released during the second step. This can be obviously related to the nature of gases. $\mathrm{HCl}$ as halogenated gas is

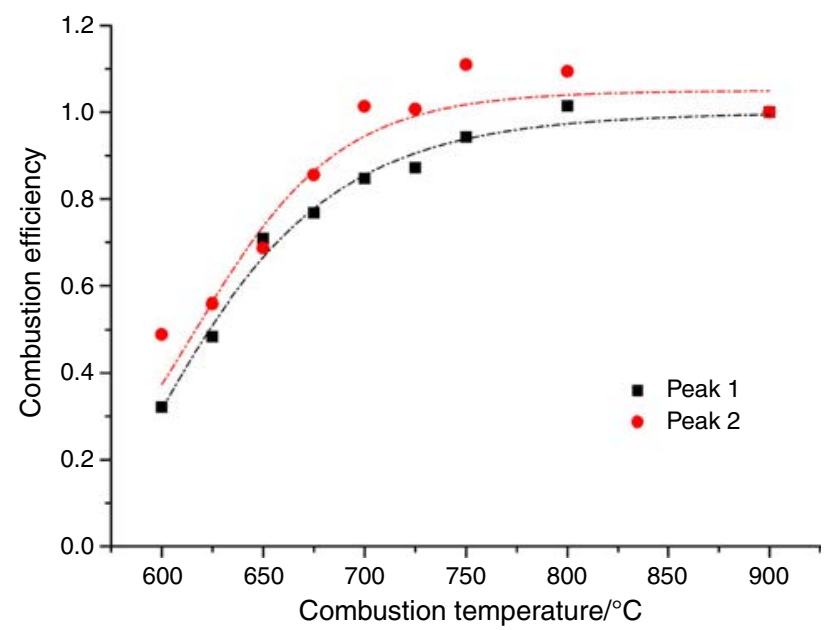

Fig. 8 Combustion efficiency versus combustion temperature for the first and second peaks of heat release rate of sheath from cable $\mathrm{C}$ able to limit the combustion of fuels. This effect is called flame inhibition and is typical of halogenated flame-retardants [33-36].

Gases were also identified after combustion at various temperatures using the PCFC-FTIR coupling. Figure 9 shows the FTIR spectra corresponding to the first decomposition peak. The first spectrum (at top) was obtained using TGA-FTIR. The others were obtained after combustion at $600-900{ }^{\circ} \mathrm{C}$ using PCFC-FTIR. Note that $\mathrm{HCl}$ does not undergo combustion. The change of the intensity of the bands corresponding to $\mathrm{HCl}$ in Fig. 9 is only apparent and due to the increase in the intensity of bands corresponding to other gases (especially $\mathrm{CO}_{2}$ ). Andersson et al. [10] also observed that $\mathrm{HCl}$ yield does not change whichever are the ventilation conditions during PVC cable burning. Speitel et al. have also noticed that hydrofluoric acid yield from polyvinylfluoride is constant whichever is the equivalence ratio in tests based on PCFC coupled with FTIR [23].

After combustion at low temperature $\left(600{ }^{\circ} \mathrm{C}\right)$, bands corresponding to phthalate $\left(1800 \mathrm{~cm}^{-1}\right)$ and aliphatic carbons (between 2800 and $3000 \mathrm{~cm}^{-1}$ ) completely disappear. $\mathrm{CO}_{2}$ and especially $\mathrm{CO}$ bands are much more intense. Bands above $3000 \mathrm{~cm}^{-1}$ are assigned to the release of $\mathrm{CH}_{4}$. Methane is produced from the decomposition of longer molecules released during anaerobic pyrolysis. Combustion leads very quickly to small molecules containing one to three carbon atoms [36].

Methane is still observed at $625^{\circ} \mathrm{C}$ but disappears at higher combustion temperature.

When temperature increases above $625{ }^{\circ} \mathrm{C}$, the $\mathrm{CO} / \mathrm{CO}_{2}$ ratio decreases continuously. Nevertheless, $\mathrm{CO}$ bands are still observed at $800{ }^{\circ} \mathrm{C}$ and disappear completely only at $900{ }^{\circ} \mathrm{C}$. It is in good agreement with combustion efficiency values. Combustion efficiency of gases released during the first decomposition step is significantly lower than 1 below $800{ }^{\circ} \mathrm{C}$ (see Fig. 8).

Figure 10 shows the spectra corresponding to the second decomposition peak. Bands corresponding to aliphatic carbons and methane observed on first spectrum (at top, obtained using TGA-FTIR) disappear completely even when the combustion temperature is as low as $600{ }^{\circ} \mathrm{C}$. The $\mathrm{CO} / \mathrm{CO}_{2}$ ratio decreases when temperature increases. $\mathrm{CO}$ bands disappear completely above $700{ }^{\circ} \mathrm{C}$. This result confirms that combustion of gases released during the second decomposition step becomes complete from $700{ }^{\circ} \mathrm{C}$, in good agreement with combustion efficiency measurements.

As already discussed, the reason for which gases released during the first decomposition step are not easily oxidized may be related to the presence of $\mathrm{HCl}$. In their study about the gases released during cable burning under well- and under-ventilated conditions, Anderson et al. also 
Fig. 9 FTIR spectra of gases from anaerobic pyrolysis with and without combustion at different temperatures at the first decomposition peak of sheath from cable C
Fig. 10 FTIR spectra of gases from anaerobic pyrolysis with and without combustion at different temperatures at the second decomposition peak of sheath from cable $\mathrm{C}$
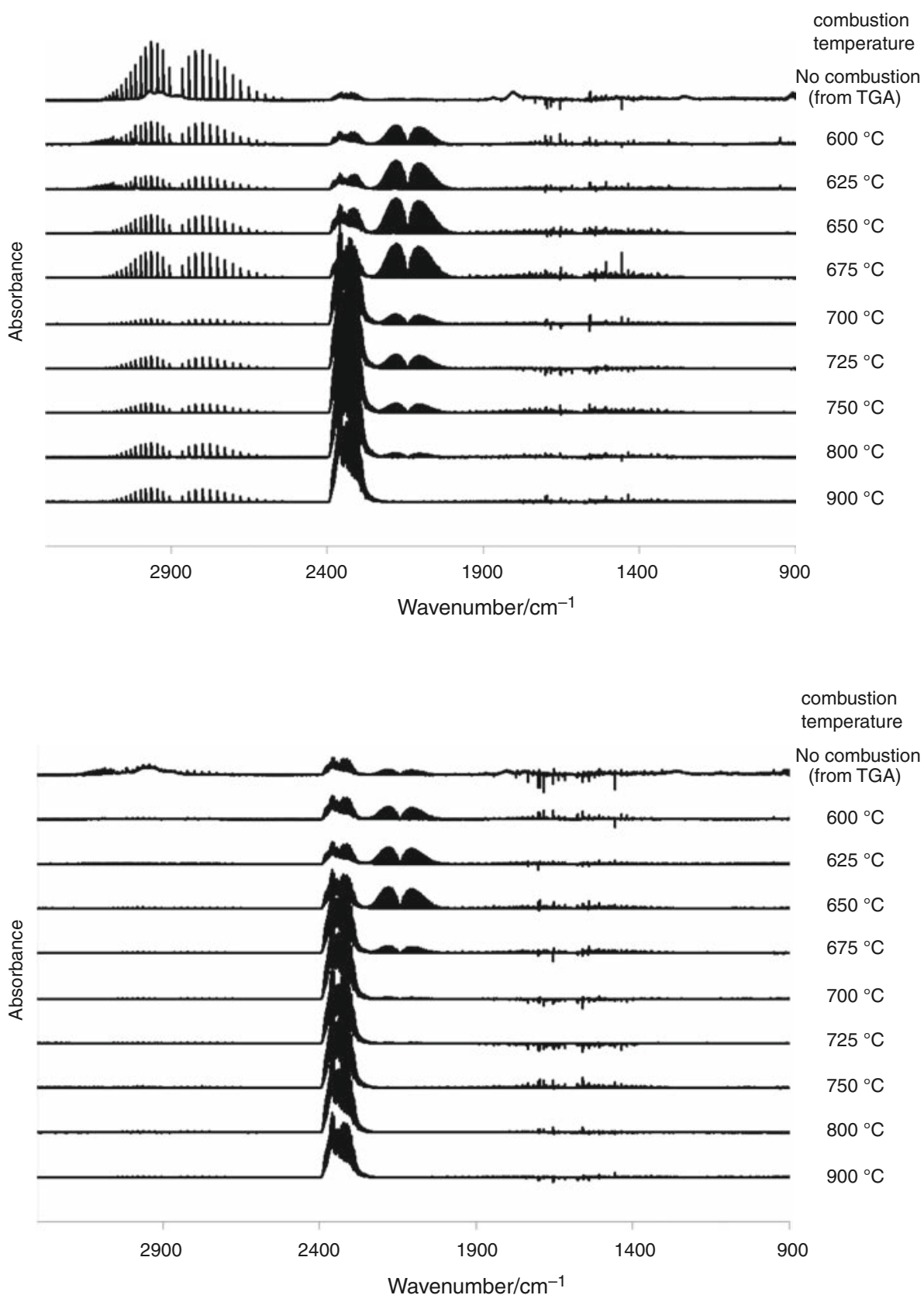

mentioned the role of chlorine species as radical scavengers. They noted that even in well-ventilated conditions, chlorine disturbs the combustion, and then, the $\mathrm{CO} / \mathrm{CO}_{2}$ ratio does not change as much for $\mathrm{PVC}$ cables than for PVC-free cables when test conditions move from well ventilated to under ventilated [10].

Figure 11 shows how the carbon from sheath is distributed after anaerobic pyrolysis and combustion at different temperatures. $16 \%$ of carbon remains in the condensed phase as char. Carbon released in the gaseous phase is growingly converted into $\mathrm{CO}_{2}$ when temperature increases. Gases containing carbon except $\mathrm{CO}_{2}$ and $\mathrm{CO}$ are observed only at low temperature $\left(600\right.$ and $\left.625^{\circ} \mathrm{C}\right)$. More than $40 \%$ of carbon is converted into these species at $600{ }^{\circ} \mathrm{C}$. But this percentage decreases very quickly. The evolution of the carbon fraction converted into $\mathrm{CO}$ is more complex. When combustion temperature increases from 600 to $650{ }^{\circ} \mathrm{C}$, none or poorly oxidized carbon products are oxidized into $\mathrm{CO}$ and compensates the oxidation of some $\mathrm{CO}$ molecules into $\mathrm{CO}_{2}$; then, $\mathrm{CO}$ fraction increases. At combustion temperature above $650{ }^{\circ} \mathrm{C}$, oxidation is easier and $\mathrm{CO}_{2}$ becomes the main oxidation product at the 


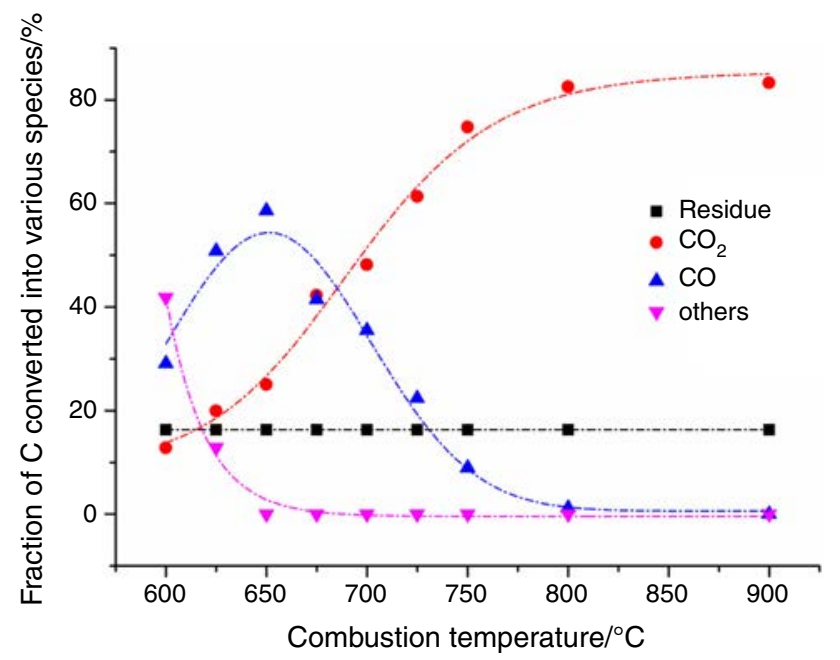

Fig. 11 Fraction of carbon converted into different species versus the combustion temperature for sheath from cable $\mathrm{C}$

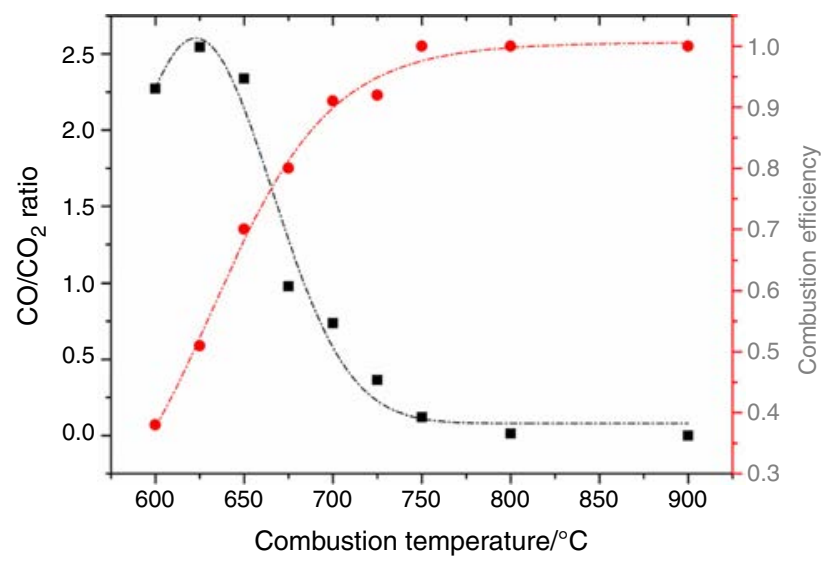

Fig. $12 \mathrm{CO} / \mathrm{CO}_{2}$ ratio and combustion efficiency versus combustion temperature for the cable $\mathrm{C}$ sheath

expense of $\mathrm{CO}$ whose fraction progressively decreases. Therefore, the carbon fraction converted into $\mathrm{CO}$ reaches a peak at intermediate temperature $\left(650{ }^{\circ} \mathrm{C}\right)$. At this temperature, this fraction reaches almost $60 \%$.

Figure 12 shows the evolution of the $\mathrm{CO} / \mathrm{CO}_{2}$ ratio and the combustion efficiency versus the combustor temperature for the cable $\mathrm{C}$ sheath. It can be observed a quite good correlation between the $\mathrm{CO} / \mathrm{CO}_{2}$ ratio and the combustion efficiency above $625{ }^{\circ} \mathrm{C}$. Higher is the temperature, lower is the $\mathrm{CO} / \mathrm{CO}_{2}$ ratio and higher is the combustion efficiency. Below $650{ }^{\circ} \mathrm{C}$, carbon is present not only as $\mathrm{CO}$ and $\mathrm{CO}_{2}$ but also as poorly oxidized species. This explains why the $\mathrm{CO} / \mathrm{CO}_{2}$ ratio decreases at $600{ }^{\circ} \mathrm{C}$ while combustion is more and more incomplete.

\section{Comparison with halogen-free flame-retardant cables}

In this section, the carbon distribution into $\mathrm{CO}, \mathrm{CO}_{2}$ and other species after combustion at various temperatures is compared for PVC cable and two halogen-free flame-retardant cables. The residue content from sheath pyrolysis is 18 mass\% for cable C (PVC-based cable) but close to 40 mass\% for cables A and B (corresponding to mineral residue from the decomposition of ATH into alumina). The decomposition of EVA/PE filled with ATH is well known and occurs into two steps. The first one (around $380{ }^{\circ} \mathrm{C}$ in TGA) corresponds to release of acetic acid from EVA and water from ATH. The second peak (around $510{ }^{\circ} \mathrm{C}$ in PCFC) corresponds to the decomposition of the remaining polymer structure (EVA and PE) [37]. As an example, TG and DTG curves for cable A sheath can be found in supporting information (Figure S1).

The decomposition kinetics is very close for both cables A and B. Gases released after combustion are also similar. Therefore, Figs. 13 and 14 show the FTIR spectra at peaks of decomposition only for cable A. For the first decomposition peak, first spectrum (at top in Fig. 13, obtained using TGA-FTIR, i.e., without combustion) reveals the presence of $\mathrm{CO}_{2}$ but also of acetic acid (bands around $1800 \mathrm{~cm}^{-1}$ ). The other spectra correspond to gases after combustion at increasing temperatures. Acid acetic is still slightly observed at $600{ }^{\circ} \mathrm{C}$ but disappears at higher temperature. Above $625^{\circ} \mathrm{C}$, only $\mathrm{CO}$ and $\mathrm{CO}_{2}$ are observed. $\mathrm{CO} / \mathrm{CO}_{2}$ ratio decreases when increasing temperature. $\mathrm{CO}$ bands disappear at temperatures above $700{ }^{\circ} \mathrm{C}$.

Figure 14 corresponds to the second decomposition peak. The first spectrum (from TGA-FTIR) shows the presence of $\mathrm{CO}, \mathrm{CO}_{2}$, aliphatic carbons (between 2800 and $3000 \mathrm{~cm}^{-1}$ ) and bands at $1730 \mathrm{~cm}^{-1}$. After combustion at $600{ }^{\circ} \mathrm{C}$, bands corresponding to aliphatic carbons disappear completely, but bands at $1730 \mathrm{~cm}^{-1}$ are still observed. But at higher temperature, only $\mathrm{CO}$ and $\mathrm{CO}_{2}$ are still observed. $\mathrm{CO}$ bands disappear even at temperatures as low as $675^{\circ} \mathrm{C}$.

Figures 15-17 show the evolution of carbon fraction converted into $\mathrm{CO}_{2}, \mathrm{CO}$ and other carbon-containing species for cables A, B and C. Note that only the carbon fraction released in gaseous phase is considered (i.e., without taking into account the carbon remaining into the char).

From Fig. 15, it is obvious that the carbon fraction converted into $\mathrm{CO}_{2}$ increases faster for halogen-free flameretardant cables $\mathrm{A}$ and $\mathrm{B}$ than for cable $\mathrm{C}$. This may be related to the presence of $\mathrm{HCl}$ in cable $\mathrm{C}$ as explained previously. Carbon is completely converted into $\mathrm{CO}_{2}$ at $675{ }^{\circ} \mathrm{C}$ for cable A and $800{ }^{\circ} \mathrm{C}$ for cable C. Cable B shows an intermediate behavior. At $700{ }^{\circ} \mathrm{C}$, the carbon fraction 
Fig. 13 FTIR spectra of gases from anaerobic pyrolysis with and without combustion at different temperatures at the first decomposition peak for the cable A sheath
Fig. 14 FTIR spectra of gases from anaerobic pyrolysis with and without combustion at different temperatures at the second decomposition peak for sheath from cable A
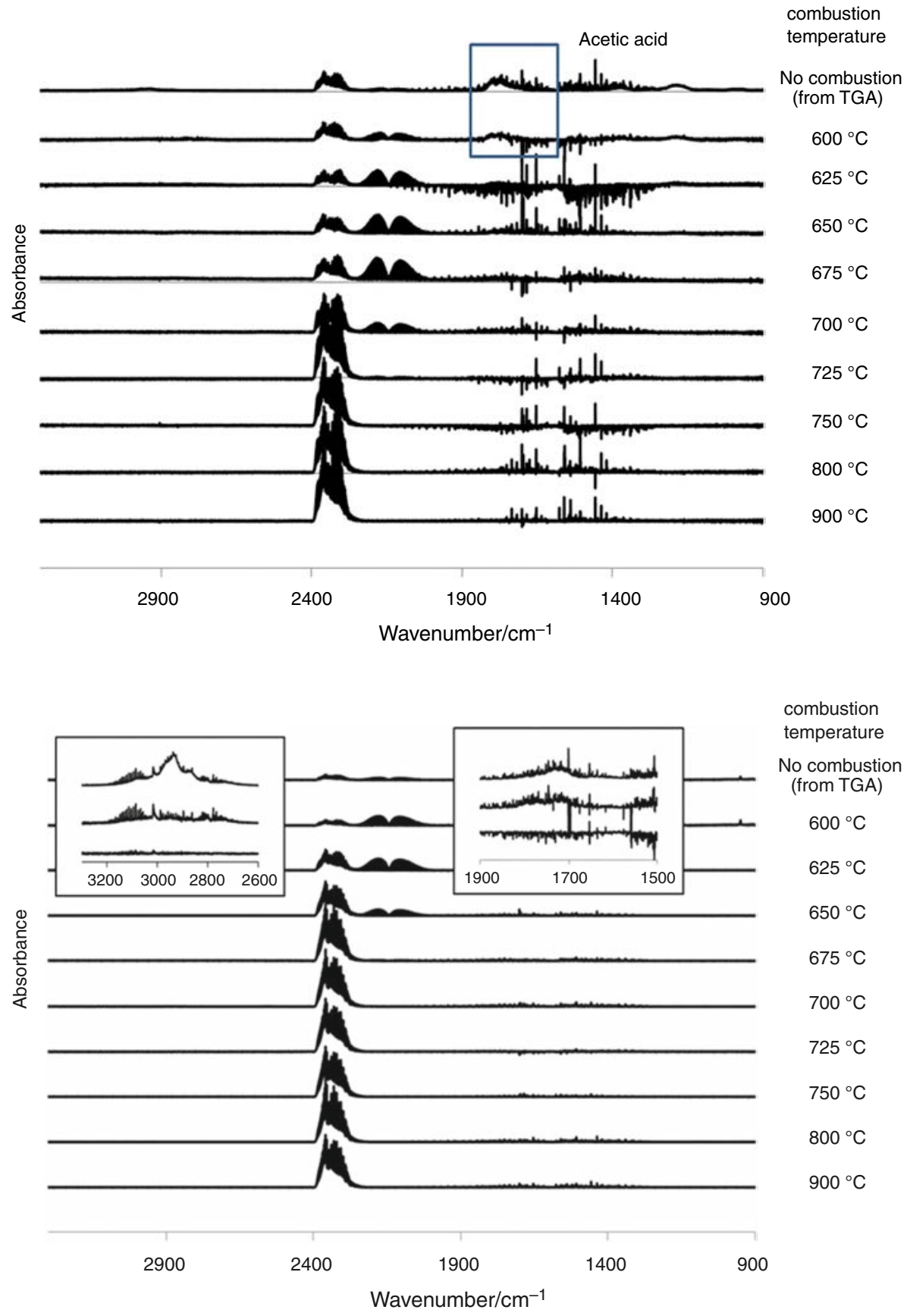

converted into $\mathrm{CO}_{2}$ is $55 \%$ for cable $\mathrm{C}$ but $85 \%$ for cable B.

Figure 16 shows the carbon fraction converted into $\mathrm{CO}$ for the three cables. All the curves exhibit a non-monotonous behavior. The carbon fraction converted into $\mathrm{CO}$ increases and then decreases when temperature increases, as already discussed for cable C. Nevertheless, the highest value of this conversion is observed at $625{ }^{\circ} \mathrm{C}$ for halogenfree flame-retardant cables versus $650{ }^{\circ} \mathrm{C}$ for cable $\mathrm{C}$. Moreover, the carbon fraction converted into $\mathrm{CO}$ is much higher for cable $\mathrm{C}$ between 650 and $800{ }^{\circ} \mathrm{C}$. This fraction becomes negligible from $675^{\circ} \mathrm{C}$ for cable $\mathrm{A}$.

Figure 17 shows the carbon fraction converted into other carbon-containing gases. These gases disappear very quickly: from $625^{\circ} \mathrm{C}$ for halogen-free flame-retardant cables and $650{ }^{\circ} \mathrm{C}$ for cable $\mathrm{C}$. The carbon fraction converted into these gases is significantly higher for cable $\mathrm{C}$ at $600{ }^{\circ} \mathrm{C}$ : $50 \%$ versus 26 and $32 \%$ for cables $\mathrm{A}$ and $\mathrm{B}$, respectively. 


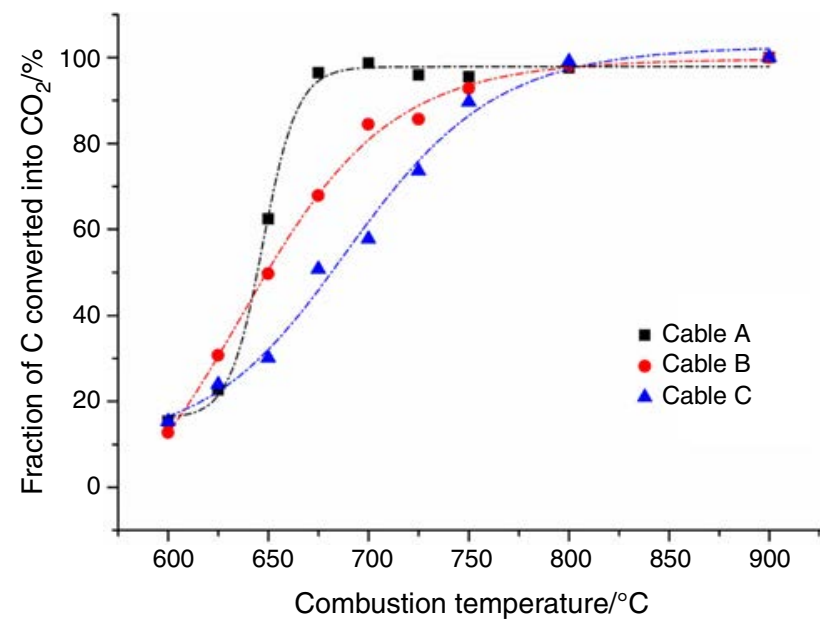

Fig. 15 Fraction of carbon converted into $\mathrm{CO}_{2}$ versus combustion temperature for cables $\mathrm{A}, \mathrm{B}$ and $\mathrm{C}$

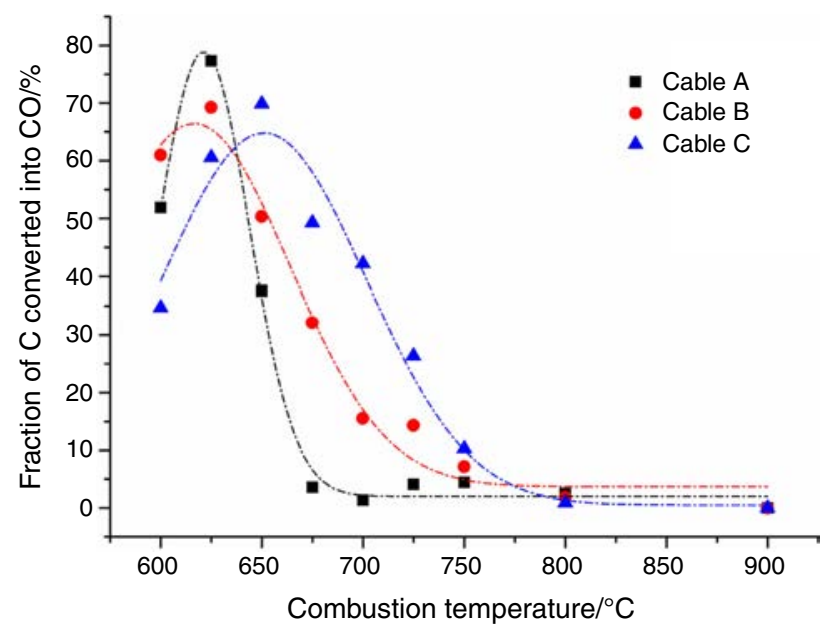

Fig. 16 Fraction of carbon converted into $\mathrm{CO}$ versus combustion temperature for cables $\mathrm{A}, \mathrm{B}$ and $\mathrm{C}$

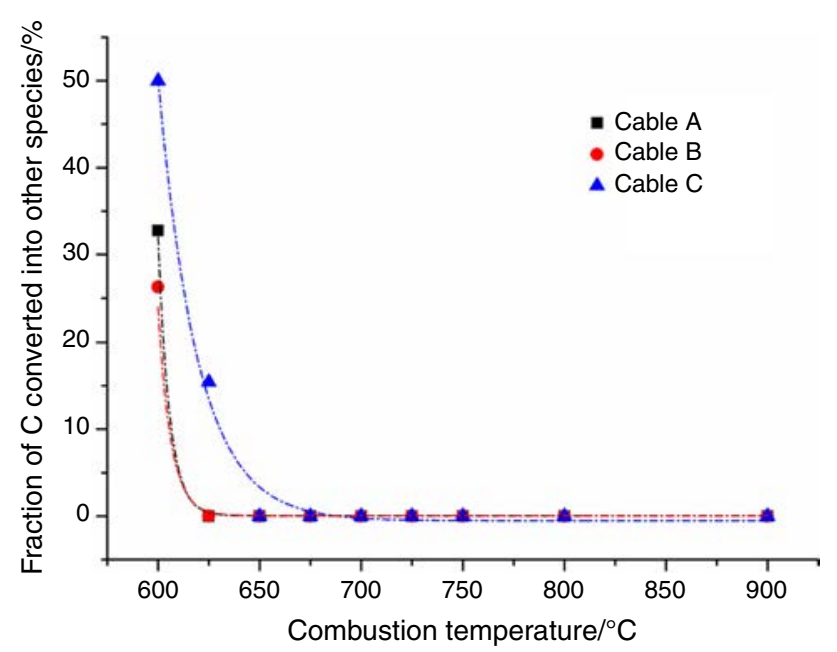

Fig. 17 Fraction of carbon converted into poorly oxidized gases versus combustion temperature for cables $\mathrm{A}, \mathrm{B}$ and $\mathrm{C}$

\section{Conclusions}

Gases released from anaerobic pyrolysis and incomplete combustion were studied for the sheaths from three cables, with a special attention paid to the PVC-based one. The PVC sheath contains plasticizer, calcium carbonate and lead-based stabilizer. This sheath decomposes into two main steps. Gases released from these two steps are different, and their tendency to be oxidized also shows significant differences. In particular, combustion becomes complete at higher temperature in the presence of $\mathrm{HCl}$, i.e., for gases released during the first decomposition step. $\mathrm{CO}$ and $\mathrm{CO}_{2}$ are obviously the two main carbon gases after combustion, but other carbon-containing species (as methane) can be observed at low combustion temperature $\left(600-650{ }^{\circ} \mathrm{C}\right)$.

Quantitative assessment of the carbon fraction converted into these different gases was carried out. In the case of cable C, $16 \%$ of carbon remains in condensed phase as char. More than $40 \%$ of carbon (50\% of carbon released in gaseous phase) is converted into poorly oxidized species at low temperature $\left(600^{\circ} \mathrm{C}\right)$. At higher temperature, this fraction decreases quickly. The carbon fraction converted into $\mathrm{CO}$ is maximum at $650{ }^{\circ} \mathrm{C}$ and is non-negligible up to $800{ }^{\circ} \mathrm{C}$. In the range $600-650{ }^{\circ} \mathrm{C}, 70-85 \%$ of carbon released in gaseous phase is not fully oxidized. This result shows that a great part of carbon released as gases can be further oxidized and then re-ignited. In real fires, incomplete combustion can also occur due to oxygen depletion. It may be assumed that a cable producing a larger amount of unburnt gases at low temperature will also produce (at least qualitatively) a larger amount of unburnt gases in underventilated conditions. This assumption needs further investigations to be evidenced.

In the case of halogen-free flame-retardant cables, poorly oxidized gases disappear above $625^{\circ} \mathrm{C}$. Carbon fraction converted into $\mathrm{CO}$ is maximum at $625^{\circ} \mathrm{C}$ and reaches $70-80 \%$ of carbon released in gaseous phase. This value is similar to the value measured for cable $\mathrm{C}$. Nevertheless, the carbon fraction converted into incompletely oxidized gases is significantly lower above $650{ }^{\circ} \mathrm{C}$ for halogen-free flame-retardant cables. Therefore, unburnt gases should accumulate in larger quantities for PVC cables than for halogen-free flame-retardant cables in similar conditions. Hence, it may be assumed that the reignition hazard is higher for PVC cables, in same real conditions. It should be added that, in real fires, incomplete combustion can be induced by other scenarios than that studied here (i.e., variation in fuel release rate or variation in oxygen concentration) and for which PCFC cannot account for. 
Acknowledgements The authors thank Dr. Belkacem Otazaghine for his help to carry out and to interpret Py-GC/MS analyses and Loïc Dumazert for his help to manage coupling analyses.

\section{References}

1. Cogen JM, Lin TS, Whaley PD. Material design for fire safety in wire and cable applications. In: Wilkie CA, Morgan AB, editors. Fire retardancy of polymeric materials. Boca Raton: CRC Press; 2010. p. 783-808.

2. IEC 60332-2-2. Tests on electric and optical fibre cables under fire conditions-part 2-2: test for vertical flame propagation for a single small insulated wire or cable-procedure for diffusion flame, Geneva, Switzerland; 2004.

3. IEC 61034-2. Measurement of smoke density of cables burning under defined conditions-part 2 test procedures, Geneva, Switzerland; 2006.

4. Hunter LW. Fire hazards of electric cables in nuclear power plants. Johns Hopkins APL Tech Dig (Appl Phys Lab). 1983;4:205-11.

5. Pretrel H, Quere P, Forestier M. Experimental study of burning rate behaviour in confined and ventilated fire compartments. Fire Saf Sci. 2005;8:1217-28.

6. Nasr A, Suard S, El-Rabii H, Gay L, Garo JP. Fuel mass-loss rate determination in a confined and mechanically ventilated compartment fire using a global approach. Combust Sci Technol. 2011;183:1342-59.

7. Melis S, Audouin L. Effects of vitiation on the heat release rate in mechanically-ventilated compartment fires. Fire Saf Sci. 2008;9:931-42.

8. Lassus J, Courty L, Garo JP, Studer E, Jourda P, Aine P. ventilation effects in confined and mechanically ventilated fires. Int $\mathbf{J}$ Therm Sci. 2014;75:87-94.

9. Delichatsios MA, Silcock GWH, Liu X, Delichatsios M, Lee Y. Mass pyrolysis rates and excess pyrolysate in fully developed enclosure fires. Fire Saf J. 2004;39:1-21.

10. Andersson P, Rosell L, Simonson M, Emanuelsson V. Small and large scale fire experiments with electric cables under well-ventilated and vitiated conditions. Fire Technol. 2004;40:27-262.

11. Audouin L, Prétrel H, Zavaleta P, OECD PRISME 2 Fire Research Project. Current status and perspectives. In: 13th International post-conference seminar on fire safety in nuclear power plants and installations; 2011-2016.

12. Zavaleta P, Audouin L. Cable tray fire tests in a confined and mechanically ventilated facility. Fire Mater. 2018;42:28-43.

13. Investigation heat and smoke propagation mechanisms in multicompartment fire scenarios, Final Report of the PRISME project, NEA/CSNI/R(2017)14, Jan 2018.

14. Meinier R, Sonnier R, Zavaleta P, Suard S, Ferry L. Fire behavior of halogen-free flame retardant electrical cables with the cone calorimeter. J Hazard Mater. 2018;342:306-16.

15. Wang Z, Wang J. An experimental study on the fire characteristics of new and aged building wires using a cone calorimeter. J Therm Anal Calorim. 2018. https://doi.org/10.1007/s10973018-7626-8.

16. Martinka J, Rantuch P, Sulova J, Martinka F. Assessing the fire risk of electrical cables using a cone calorimeter. J Therm Anal Calorim. 2018. https://doi.org/10.1007/s10973-018-7556-5.

17. Sonnier R, Otazaghine B, Ferry L, Lopez-Cuesta JM. Study of the combustion efficiency of polymers using a pyrolysis-combustion flow calorimeter. Combust Flame. 2013;160:2182-93.

18. Sonnier R, Dorez G, Vahabi H, Longuet C, Ferry L. FTIR-PCFC coupling: a new method for studying the combustion of polymers. Combust Flame. 2014;161:1398-407.
19. Guo H, Lyon RE, Safronava N, Walters RN, Crowley S. A simplified model of carbon monoxide yield in burning of polymeric solids containing flame retardants. Fuel. 2018;222:175-9.

20. Walters RN, Safronava N, Lyon RE. A microscale combustion calorimeter study of gas phase combustion of polymers. Combust Flame. 2015;162(3):855-63.

21. Guo H, Lyon RE, Safronava N, Walters RN, Crowley S. Kinetics of carbon monoxide yield in burning of polymeric solids containing flame retardants. In: 28th Annual conference on recent advances in flame retardancy of polymeric materials, FLAME, Newton; 2017.

22. Guo H, Lyon RE, Safronava N, Walters RN, Crowley S. Kinetic effects of carbon monoxide yield in burning of polymeric solids containing flame retardants. In: 10th U.S. national combustion meeting, College Park; 2017.

23. Speitel L, Walters RN, Lyon RE. Toxicity assessment of polymers at constant fuel/oxygen ratios in the microscale combustion calorimeter. San Francisco: Fire and Materials; 2017.

24. Walters RN, Speitel L, Lyon RE. Combustion products of polymers at constant fuel/oxygen ratios. In: INTERFLAM 2016, Royal Holloway College, London; 4-6 July 2016.

25. Guo H, Lyon RE, Safronava N, Walters RN, Crowley S. A simplified model of carbon monoxide yield in burning of polymeric solids containing flame retardants. In: 10th Mediterranean combustion symposium, Naples; 2017.

26. Plumecocq W, Audouin L, Zavaleta P. Horizontal cable tray fire in a well-confined and mechanically ventilated enclosure using a two-zone model. Fire and Materials; 2019. https://doi.org/10. 1002/fam.2698.

27. Schartel B, Pawlowski K, Lyon R. Pyrolysis combustion flow calorimeter: A tool to assess flame retarded PC/ABS materials? Thermochim Acta. 2007;462:1-14.

28. Folarin O, Eromosele I, Eromosele C. Thermal stabilization of poly(vinyl chloride) by metal carboxylates of Ximenia Americana seed oil under inert condition. J Mater Environ Sci. 2012;3:507-14.

29. Liu P, Zhao M, Guo J. Thermal stabilities of poly(vinyl chloride)/calcium carbonate $\left(\mathrm{PVC} / \mathrm{CaCO}_{3}\right)$ composites. J Macromol Sci Part B Phys. 2006;45:1135-40.

30. Hlaing Z, Wajima T, Uchiyama S, Nakagome H. Reduction of bromine compounds in the pyrolysis oil of computer casing plastics using shell, $\mathrm{Ca}(\mathrm{OH})_{2}$ and $\mathrm{NaOH}$. APCBEE Procedia. 2014;10:193-7.

31. McNeill I, Memetea L. Pyrolysis products of poly(vinyl chloride), dioctyl phthalate and their mixture. Polym Degrad Stab. 1994;43:9-25.

32. Benes M, Milanov N, Matuscek G, Kettrup A, Placek V, Balek V. Thermal degradation of PVC cable insulation studied by simultaneous TG-FTIR and TG-EGA methods. J Therm Anal Calorim. 2004;78:621-30.

33. Babushok V, Tsang $\mathrm{W}$. Inhibitor rankings for alkane combustion. Combust Flame. 2000;123:488-506.

34. Noto T, Babushok V, Burgess DR Jr, Hamins A, Tsang W, Miziolek A. Effect of halogenated flame inhibitors on $\mathrm{C}_{1}-\mathrm{C}_{2}$ organic flames. In: 26th Symposium on combustion/the combustion institute; 1996. p. 1377-1383.

35. Noto T, Babushok V, Hamins A, Tsang W. Inhibition effectiveness of halogenated compounds. Combust Flame. 1998;112:147-60.

36. Babushok V, Tsang W, Linteris GT, Reinelt D. Chemical limits to flame inhibition. Combust Flame. 1998;115:551-60.

37. McGarry K, Zilberman J, Hull TR, Woolley WD. Decomposition and combustion of EVA and LDPE alone and when fire retarded with ATH. Polym Int. 2000;49:1193-8. 